\title{
Penggunaan Traktor Roda Dua pada Lahan Padi Sawah di Jawa Barat
}

\author{
Saeful Bachrein, Agus Ruswandi dan Trisna Subarna \\ Badan Perencanaan dan Pembangunan Daerah Provinsi Jawa Barat \\ Jl. Ir. H. Juanda 287 Bandung 40135 \\ Korespondensi: bachreins@yahoo.com
}

\begin{abstract}
Two-wheel tractor utilization in paddy land in West Java

Agribusiness-oriented low land rice development should be supported by agricultural machanization such as two-wheel tractor utilization. The objective of this assesment was to evaluate the actual utilization rate, existing performance and feasibility of two-wheels tractor utilization in lowland rice farming system in West Java. Assesment has been done using this assesment was also aimed to make two-wheel tractor utilization approachment in West Java based on actual facts and government policyes. Participatory Rural Appraisal and Survey Method. Results demonstrated that tractor availability was fairly good with household partisipatory rate at rainy and drought season up to $96 \%$ and $97 \%$ respectively. Rental business of two-wheels tractor was relatively profitable as indicated by the value of $\mathrm{R} / \mathrm{C}$ ratio greater than one (1.54), ), pay back period 2.74 years, and break event point 30.77 ha year ${ }^{-1}$. Some social, cultural and technical problems in the utilization of two-wheel tractors for cultivating lowland rice field in West Java has been verified.
\end{abstract}

Key Word: Business feasibility, Performance, Two-whells tractor

\begin{abstract}
ABSTRAK
Pengembangan komoditas padi sawah yang berorientasi agribisnis seharusnya didukung oleh alat dan mesin pertanian antara lain traktor moda dua. Kajian ini dilakukan untuk mengevaluasi tingkat penggunaan, keragaan dan kelayakan penggunaan traktor roda dua di lahan padi sawah di Jawa Barat. Kajian ini juga bertujuan untuk membuat pendekatan pengembangan traktor roda dua di Jawa Barat berdasarkan kenyataan di lapangan dan kebijakan pemerintah. Kajian ini dilaksanakan melalui metode Pemahaman Pedesaan Partisipatif dan survey terstruktur. Hasil pengkajian menunjukkan bahwa ketersediaan traktor relatif memadai dengan tingkat partisipasi rumah tangga pengguna di musim hujan dan kemarau masing-masing $96 \%$ dan $97 \%$. Usaha jasa traktor layak diusahakan karena memberikan nilai Revenue-Cost Rasio 1,36 dan Pay Back Period 2,74 per tahun dan titik Impas 30,77 ha/tahun. Pada penelitian ini, beberapa masalah sosial, budaya dan teknis dalam pengembangan traktor roda dua pada padi sawah di Jawa Barat telah diinventarisasi.
\end{abstract}

Kata Kunci: Kelayakan usaha, Keragaan, Traktor roda dua

\section{PENDAHULUAN}

Jawa Barat, dengan luas lahan sawah irigasi mencapai 926.782 ha pada tahun 2007, adalah salah satu lumbung pangan nasional (Diperta Jawa Barat, 2007). Kabupaten Karawang, Indramayu, Bandung, Cianjur, Ciamis and Garut berperan penting dalam produksi beras di Jawa Barat. Di daerah irigasi teknis, kekurangan tenaga kerja menyebabkan waktu pengolahan tanah mundur dan periode pemberian air bertambah panjang (Ananto et al., 2004). Akibatnya, terdapat resiko kekurangan air pada pertanaman padi musim gadu, dan tidak ada penanaman palawija setelah padi di musim kemarau. 
Masalah tersebut dapat diatasi dengan penggunaan traktor yang mempersingkat waktu persiapan tanah sehingga intensitas tanam meningkat. Berdasarkan data Pemprov Jabar (2004-2006), traktor yang paling banyak digunakan adalah traktor roda dua dengan daya $<15 \mathrm{PK}$. Pengolahan tanah dengan traktor mempercepat dan menjamin keseragaman waktu tanam serta meningkatkan intensitas tanam sampai 20 \% (Ananto et al., 1993). Pada lahan sawah irigasi, bajak singkal pada traktor mampu mengolah tanah sedalam $17 \mathrm{~cm}$, menurunkan kekerasan tanah sebesar $0,37 \mathrm{~kg} \mathrm{~cm}^{-2}$ serta meningkatkan hasil padi sebesar 8,8 \% dan 19,5\% dibandingkan dengan lahan yang diolah dengan ternak dan cangkul (Ananto, 1992). Namun penggunaan traktor juga dapat menggeser tenaga kerja mencangkul sebesar 23 \% per ha (Ananto, 1992).

Penggunaan traktor juga mengantisipasi rendahnya tenaga kerja tani di pedesaan karena tenaga kerja muda cenderung bekerja di luar sektor pertanian. Akibatnya, tenaga kerja di pedesaan relatif tua dengan pendidikan dan produktivitas relatif rendah. Curahan hari kerja untuk pengolahan tanah hanya 13-15 hari, panen dan pasca panen 21 hari per tahun, sementara hari kerja efektif di sektor industri dan jasa berkisar 96-289 hari per tahun (Ananto et al., 2004).

Hingga saat ini, masalah dalam pemanfaatan traktor khususnya traktor roda dua untuk mendukung pengembangan agribisnis di Jawa Barat belum diinventarisasi. Belum ada data maupun informasi mengenai keragaan dan kelayakan penggunaan serta pengembangannya di tingkat petani secara terinci dan menyeluruh. Padahal traktor jenis ini sesuai dengan kondisi lahan sawah di Jawa Barat dengan petakan relatif sempit dan biaya operasional tinggi. Data dan informasi tersebut sangat diperlukan untuk menyusun strategi pengembangan padi sawah yang berorientasi kepada swasembada pangan. Dengan demikian, kajian ini dilakukan untuk mengevaluasi tingkat penggunaan, keragaan dan kelayakan penggunaan traktor roda dua pada padi sawah, di beberapa pusat produksi padi sawah di Jawa Barat. Kajian ini juga bertujuan untuk membuat pendekatan pengembangan traktor roda dua di Jawa Barat berdasarkan kenyataan di lapangan dan kebijakan pemerintah.

\section{BAHAN DAN METODE}

Pengkajian ini dilaksanakan dari bulan Januari hingga Desember 2008 di enam Kabupaten, yaitu Karawang dan Indramayu yang mewakili wilayah pembangunan utara, Bandung dan Cianjur yang mewakili wilayah pembangunan tengah, serta Ciamis dan Garut yang mewakili wilayah pembangunan selatan. Di setiap Kabupaten ditentukan dua desa dari dua kecamatan yang potensial dalam penggunaan traktor roda dua (Tabel 1).

Tabel 1. Lokasi kajian pemanfaatan traktor roda dua padi sawah di enam kabupaten

\begin{tabular}{|c|c|}
\hline Kabupaten & Kecamatan (Desa) \\
\hline \multirow[t]{2}{*}{ Karawang } & 1. Tirtamulya (Citarik, Cipondok) \\
\hline & $\begin{array}{l}\text { 2. Telagasari (Pasirmukti, } \\
\text { Kalibuaya) }\end{array}$ \\
\hline \multirow[t]{2}{*}{ Indramayu } & $\begin{array}{l}\text { 1. Gabus Wetan (Kedokan Gabus, } \\
\text { Sukamelang) }\end{array}$ \\
\hline & $\begin{array}{l}\text { 2. Anjatan (Kedungwungu, } \\
\text { Mangunjaya) }\end{array}$ \\
\hline \multirow[t]{2}{*}{ Bandung } & $\begin{array}{l}\text { 1. Selokan Jeruk (Bojong Emas, } \\
\text { Selokan Jeruk) }\end{array}$ \\
\hline & $\begin{array}{l}\text { 2. Kotawaringin (Kotawaringin, } \\
\text { Cibodas) }\end{array}$ \\
\hline \multirow[t]{2}{*}{ Cianjur } & $\begin{array}{l}\text { 1. Ciranjang (Kertamukti, } \\
\text { Ciranjang) }\end{array}$ \\
\hline & 2. Cilaku (Sukasari, Sindangsari) \\
\hline \multirow[t]{2}{*}{ Ciamis } & $\begin{array}{l}\text { 1. Banjarsari (Sindangasih, } \\
\text { Sindanghayu) }\end{array}$ \\
\hline & 2. Lakbok (Sukanagara, Baregbeg) \\
\hline \multirow[t]{2}{*}{ Garut } & 1. Bungbulang (Bojong, Sinar Jaya) \\
\hline & 2. Kadungora (Kadungora, Cisaat) \\
\hline
\end{tabular}

Pengumpulan data dilakukan dengan dua metode yaitu Pemahaman Pedesaan Partisipatif (Participatory Rural Appraisal/PRA) dan survey terstruktur. PRA menggunakan wawancara semi terstuktur dengan informan kunci yaitu kelompok tani, petani andalan dan pengusaha andalan (Chamber, 1992). Survey terstruktur dilakukan melalui wawancara menggunakan kuesioner untuk mengambil kesimpulan secara menyeluruh (Mathias, 1994).

Data yang diperoleh dari PRA dan wawancara dengan kuesioner dianalisis secara deskriptif. Analisis finansial berupa Net Revenue Cost ratio (Net $\mathrm{R} / \mathrm{C})$, titik impas, dan Pay Back Period (PBP) (Badan Litbang Pertanian, 2005). Berdasarkan kriteria analisis finansial tersebut penggunaan traktor roda 2 akan disimpulkan layak jika NPV > 0, Net B/C > 1, dan IRR lebih besar dari bunga bank yang berlaku. 


\section{HASIL DAN PEMBAHASAN}

Pada tahun 2007 luas lahan sawah di Jawa Barat adalah 926.782 ha, meningkat dibandingkan dengan tahun 2006, meskipun masih lebih rendah daripada tahun 2003 (Diperta Propinsi Jawa Barat, 20032007). Sebesar $85 \%$ lahan sawah tersebut ditanami padi dua kali dan sisanya ditanami padi satu kali per tahun Kondisi ini menunjukkan bahwa potensi pengem-bangan traktor roda-2 sangat tinggi untuk mendukung pengembangan produksi padi sawah. Jumlah traktor roda dua pada tahun 2005 (13.520 unit) lebih rendah daripada tahun 2004 (16.945 unit) tetapi meningkat kembali menjadi 15.654 unit pada tahun 2006 dan 16.970 unit pada tahun 2007 (Diperta Jawa Barat, 2004-2007).

\section{Tingkat Penggunaan Jasa Traktor Roda Dua}

Kajian ini menjelaskan bahwa penggunaan jasa traktor roda dua oleh petani di ketiga wilayah pengembangan sangat tinggi dan mencapai rata-rata $96 \%$ saat musim hujan dan $97 \%$ saat musim kemarau (Tabel 2). Simatupang et al. (1995) melaporkan bahwa kebutuhan jenis traktor berbeda antar lokasi sesuai dengan sumberdaya lahan, sumberdaya air, dan ketersediaan tenaga kerja.

Tabel 2. Tingkat partisipasi rumah tangga pengguna traktor roda-2 di Jawa Barat

\begin{tabular}{lcccc}
\hline \multirow{2}{*}{$\begin{array}{l}\text { Musim } \\
\text { Tanam }\end{array}$} & \multicolumn{2}{c}{ Wilayah Pengembangan } & Rata- \\
\cline { 2 - 3 } & Utara & Tengah & Selatan & rata \\
\hline------ & 100 & 95 & 92 & 96 \\
$\begin{array}{l}\text { Musim } \\
\text { Hujan }\end{array}$ & & & & \\
$\begin{array}{l}\text { Musim } \\
\text { Kemarau }\end{array}$ & 100 & 100 & 92 & 97 \\
\hline
\end{tabular}

Beberapa petani di wilayah pengembangan selatan dan tengah, khususnya di lahan sawah tadah hujan, tetap menggunakan tenaga kerja manusia untuk pengolahan tanah karena keterbatasan modal, ketersediaan tenaga kerja keluarga serta topografi yang relatif bergelombang dan bergunung sehingga sukar untuk dimasuki traktor.

Umumnya petani menyewa traktor kepada para pemilik. Sistem pembayaran upah sewa traktor adalah: 1) dibayar setelah selesai pengolahan tanah dan penanaman padi, 2) dibayar setelah panen dan 3) dibayar 1-2 minggu setelah pengolahan tanah selesai. Di semua kabupaten/kecamatan, luas operasi traktor adalah 20 ha per musim atau 40 ha per tahun dengan biaya sewa $\mathrm{Rp} 550.000 \mathrm{ha}^{-1}$. Masa operasi dalam satu musim pengolahan tanah sekitar 20-30 hari. Kemampuan traktor untuk mengolah lahan per hari (sekitar 7-8 jam kerja) bervariasi antara 0,4-0,6 ha sampai siap tanam. Wilayah operasi traktor mencakup beberapa desa dalam satu kecamatan, kecuali di Kabupaten Bandung karena terjadi mobilisasi traktor antar kecamatan.

Kendala penggunaan traktor yang berkesinambungan adalah bengkel di masing-masing wilayah relatif terbatas sehingga menyulitkan petani apabila terjadi kerusakan traktor. Selain itu, ketrampilan operator relatif rendah sehingga saat ini efisiensi pengusahaan traktor cukup sulit untuk ditingkatkan.

\section{Kelayakan Usaha Jasa Sewa Traktor Roda Dua}

Di ketiga wilayah pengembangan Jawa Barat, biaya operasional traktor roda dua relatif sama. Faktor pembeda kelayakan usaha jasa traktor antar wilayah dapat dilihat dari nilai R/C, Pay Back Period dan titik impas. Rata-rata R/C usaha traktor roda dua adalah 1,36. Artinya usaha tersebut mampu memberikan penerimaan sebesar 1,36 kali biaya (Tabel 3) atau keuntungan bersih $36 \%$. Pay Back Period Jasa sewa traktor ini adalah 2,74, berarti biaya investasi dapat dikembalikan dalam tempo 2,74 tahun yang lebih rendah daripada umur ekonomis traktor yaitu 5 tahun. Titik impas tercapai jika traktor roda dua mampu mengolah lahan sawah seluas 30,77 ha per tahun, lebih rendah daripada kapasitas kerjanya yang mampu mencapai 50 ha per tahun. Hasil ini sesuai dengan yang dilaporkan oleh Badan Litbang Pertanian (2005) bahwa usaha jasa

Tabel 3. Kelayakan usaha jasa traktor roda-2 di Jawa Barat pada tahun 2008

\begin{tabular}{lrccc}
\hline \multirow{2}{*}{ Uraian } & \multicolumn{3}{c}{ Wilayah Pengembangan } & \multirow{2}{*}{ Rata-Rata } \\
\cline { 2 - 4 } & Utara & Tengah & Selatan & \\
\hline Keuntungan sewa (Juta Rp th ${ }^{-1}$ ) & 5,17 & 6,93 & 5,86 & 5,99 \\
R/C rasio & 1,31 & 1,39 & 1,37 & 1,36 \\
Pay Back Period (tahun) & 3,12 & 2,38 & 2,73 & 2,74 \\
Titik Impas (ha) & 30,59 & 32,40 & 29,33 & 30,77 \\
\hline
\end{tabular}


traktor roda dua layak untuk diusahakan secara luas ditingkat petani karena memberikan $\mathrm{R} / \mathrm{C}$ rasio 1,49 , Pay Back Period sebesar 1,76, dan titik impas 34 ha.

\section{Kendala dan Permasalahan Pengembangan Traktor Roda-2}

Kendala dan permasalahan pengembangan traktor roda dua pada padi sawah di Jawa Barat dapat dibagi atas beberapa aspek, yaitu kelayakan traktor, kondisi ekonomi dan sosial budaya, kelembagaan pendukung, dan kebijakan.

\section{a. Kelayakan Traktor Roda-2 yang Dikembangkan}

Berdasarkan kegagalan penggunaan traktor pada periode sebelumnya, beberapa tahun terakhir ini telah diintroduksi alat mesin pertanian skala kecil yang relatif lebih sesuai secara teknik di lapangan dan modal petani maupun kelompok tani. Jenis traktor yang diintroduksikan juga mengalami perubahan dari traktor roda dua dengan tenaga 13,518,0 PK dan rumit menjadi traktor roda dua yang sederhana dengan tenaga 8,5-10,5 PK yang harganya murah (Soentoro, 1998).

Traktor roda dua produksi dalam negeri dengan spesifikasi yang sesuai dengan tanah Indonesia belum banyak digunakan di tingkat petani padi sawah di Jawa Barat. Umumnya petani menggunakan traktor roda dua dari Jepang yang mata bajak dan rotarinya perlu dimodifikasi karena kurang sesuai dengan kondisi tanah di Jawa Barat yang berliat tinggi. Tanah akan sangat keras di musim kemarau dan lekat bila basah. Selain itu, pengujian dan evaluasi penggunaan traktor roda dua pada berbagai tipe lahan (agroekosistem) belum dilaksanakan secara optimal dan berkelanjutan sehingga kebutuhannya di tingkat petani belum teridentifikasi. Akibatnya, traktor roda dua yang dihasilkan oleh lembaga penelitian dan pengembangan instansi terkait dan industri tidak seluruhnya dapat diserap dan digunakan oleh petani.

Masalah yang muncul dalam pengembangan traktor roda dua di enam kabupaten di Jawa Barat telah diinventarisasi. Selain itu akar penyebab masalah yang sekaligus menjadi tantangan untuk penyempuraan penggunaan traktor telah diketahui. Masalah tersebut adalah:

a. Ketidaklayakan traktor yang disebabkan oleh stagnasi inovasi teknologi traktor dan lemahnya lembaga diseminasi inovasi teknologi.

b. Kondisi ekonomi dan sosial budaya kurang mendukung yang disebabkan oleh 1) rendahnya modal petani 2) adanya bisnis traktor yang tidak adil dan 3) rendahnya kemampuan/ pengetahuan operator dan manajemen usaha.

c. Lemahnya kelembagaan pendukung yang disebabkan oleh 1) kelompok tani tidak berfungsi sesuai kaidahnya, 2) stagnasi pengembangan industri alsintan dan 3) stagnasi usaha pelayanan jasa alat dan mesin pertanian (alsintan).

d. Kebijakan pemerintah kurang efektif karena 1) program pengembangan traktor tidak spesifik lokasi, 2) tidak ada pembinaan lebih lanjut dan 3) pengembangan traktor tidak disinergikan/ disinkronkan dengan program lainnya (pengembangan agribisnis padi

\section{b. Kondisi Ekonomi dan Sosial Budaya}

Ketersediaan modal bagi pengembangan alsintan di pedesaan merupakan hal yang dilematis. Penyedia jasa keuangan informal dengan bunga cukup tinggi tumbuh subur tetapi akses petani terhadap modal yang disediakan lembaga keuangan formal masih rendah.

Keterbatasan petani terhadap sumber permodalan dari lembaga keuangan formal disebabkan oleh antara lain 1) keterbatasan lembaga keuangan formal di pedesaan, 2) prosedur dan persyaratan masih dinilai sulit oleh masyarakat pedesaan, dan 3) alokasi kredit cenderung kecil dan menggunakan standar sektor nonagribisnis yang karakteristiknya berbeda. Dari hasil pengamatan, lebih dari $50 \%$ traktor yang tersedia saat ini sudah berumur lebih dari 5 tahun (umur ekonomis dari traktor). Penambahan traktor baru sulit dilakukan kecuali untuk menggantikan traktor lama karena adanya pembagian wilayah kerja traktor.

Berdasarkan kondisi di atas, untuk menunjang keberhasilan pengembangan traktor roda dua di masa depan perlu diperhatikan beberapa hal, antara lain:

1. Jenis traktor yang dikembangkan harus secara ekonomis menguntungkan dalam arti bahwa alsintan tersebut dapat beroperasi dalam jangka panjang, relatif murah, dan kebutuhan akan alat tersebut relatif tinggi. Sedangkan, secara sosial dapat diterima, artinya pengembangan alsintan bersifat melengkapi (complement) dan tidak terjadi penggantian (substitution) tenaga kerja manusia yang ada sehingga menimbulkan pengangguran.

2. Pengembangan traktor harus didukung oleh program lainnya yang mendukung, seperti: penyediaan suku cadang, ketersediaan bengkel, dan peningkatan ketrampilan sumberdaya manusia (operator, manajer, dan lain-lain). 
3. Pengembangan traktor tidak mungkin terjadi tanpa fasilitasi dari pemerintah terutama yang terkait dengan permodalan, bantuan langsung, kemitraan antara kelompoktani/gapoktan dengan swasta, bimbingan teknis, dan pengembangan infrastruktur pedesaan.

\section{c. Kelembagaan Pendukung}

Keberhasilan pengembangan traktor roda dua tidak terlepas dari kinerja kelembagaan pendukung, seperti kelompok tani/gapoktan, lembaga penyuluhan, institusi permodalan, lembaga pelatihan usaha industri dan jasa yang saling terkait dan saling bergantung satu sama lain. Dengan demikian, pengembangan alsintan seharusnya dilaksanakan melalui pendekatan sistem yang komprehensif Konsep pengembangan alsintan seharusnya juga spesifik lokasi dan terpadu sehingga dioperasionalkan sesuai dengan kebutuhan setempat.

Sebagian besar kelompok tani/gapoktan yang telah terbentuk ternyata belum menerapkan kaidah berkelompok secara optimal, sehingga cenderung stagnan. Oleh karena itu, pembinaan kelompok tani/gapoktan mutlak diperlukan dalam upaya mendukung keberhasilan pengembangan traktor roda dua di tingkat petani.

Sejak otonomi daerah diberlakukan, pengelolaan penyuluhan pertanian diserahkan kepada pemerintah daerah kabupaten yang menyebabkan sistem diseminasi inovasi teknologi menjadi kurang optimal karena kurangnya perhatian sebagian besar pemda terhadap penyuluhan pertanian. Dengan dicanangkannya revitalisasi penyuluhan sebagai salah satu program utama Departemen Pertanian diharapkan proses inovasi teknologi pertanian dapat segera pulih dan menjadi penggerak terdepan pengembangan alsintan padi sawah di masa datang.

Perkembangan mekanisasi pertanian tidak terlepas dari peranan industri alsintan swasta. Namun industri alsintan sering terlambat menghasilkan alsintan yang sesuai dan dibutuhkan petani dengan harga yang relatif mahal. Jumlah industri kecil alsintan di pedesaan/kecamatan cenderung menurun pada beberapa tahun terakhir ini disebabkan karena kendala sumber daya manusia, kualitas produk dan persaingan dengan produk impor.

\section{Kebijakan Pemerintah}

Program pengembangan alsintan pra panen dan pasca panen diarahkan untuk meningkatkan efisiensi, mutu, nilai tambah, dan daya saing, serta menumbuhkembangkan kelembagaan usaha agribis- nis dan agroindustri, peningkatan pendapatan dan kesejahteraan petani di pedesaan (Deptan, 2006).

Dari hasil pengamatan ternyata pelaksanaan kebijakan/program yang telah disusun oleh Pemerintah Pusat dan Provinsi Jawa Barat terkait dengan pengembangan alsintan umumnya belum optimal karena menghadapi berbagai permasalahan/ kendala, antara lain:

1. Sebagian besar kabupaten/kota tidak membuat petunjuk teknis (Juknis) sehingga pelaksanaan kurang lancar dengan hasil tidak seperti yang diharapkan.

2. Pembagian kewenangan antara Pemerintah Daerah Provinsi Jawa Barat dengan Pemerintah Daerah Kabupaten/Kota cenderung tumpang tindih dengan koordinasi dan sinkronisasi sangat rendah, termasuk dari segi dukungan dana dan penentuan jenis traktor.

3. Program pengembangan traktor terfokus pada penyediaan bantuan traktor, sehingga penerima bantuan umumnya tokoh masyarakat yang relatif kaya karena dianggap mampu mengoperasionalkan dan merawatnya. Akibatnya, traktor tersebut cenderung menjadi milik perorangan dan petani membayar sewa kepada pemilik.

4. Tidak ada koordinasi pelaksanaan dan sinkronisasi program pengembangan traktor antar sub-dinas dalam satu instansi/dinas dan antar instansi/dinas terkait sehingga hasilnya tidak optimal.

\section{Pendekatan Pengembangan Traktor Roda Dua di Jawa Barat}

Dari uraian di atas, beberapa hal yang perlu diperhatikan dalam mendukung keberhasilan pengembangan traktor dua roda di lahan sawah adalah perencanaan yang terkoordinasi dari bawah ke atas dan dari atas ke bawah. Perencanaan dari bawah (tingkat kabupaten) tentunya dirumuskan berdasarkan kehendak dan kemampuan masyarakat/ petani setempat. Pengembangan traktor roda dua harus dilaksanakan melalui beberapa pendekatan, yaitu pendekatan sistem, pendekatan wilayah dan pendekatan sumber daya manusia.

\section{a. Pendekatan Sistem}

Keberhasilan pemanfaatan traktor secara luas di tingkat petani sangat dipengaruhi dan berinteraksi oleh/dengan faktor-faktor lainnya, seperti aspek teknis, usahatani/budidaya, sumberdaya, permodalan, sosial, lingkungan dan kebijakan pemerintah. Sistem juga dapat terdiri atas beberapa sub-sistem, 
yaitu penelitian dan pengembangan, penyuluhan, pengrajin/pabrikan, dan pengguna (petani). Semua sub-sistem tersebut terkait satu sama lain dalam suatu jejaring kerjasama dengan mekanisme kerja yang terarah dan terkoordinasi dalam suatu program/kegiatan yang terpadu, konsisten dan berkelanjutan.

\section{b. Pendekatan Wilayah}

Perlu dipilih alternatif model pengembangan traktor tepat guna yang sesuai dengan keunikan suatu wilayah tertentu khususnya potensi sumberdaya, agro-ekologi, tingkat perkembangan ekonomi dan sosial budaya. Perhatian utama dalam pendekatan wilayah adalah 1) pengembangan traktor dalam kerangka agribisnis ditekankan pada peningkatan pendapatan rumah tangga pertanian di wilayah, sehingga kesenjangan pendapatan dan taraf hidup rumah tangga antar wilayah dapat diperkecil dan 2) pilihan traktor yang dikembangkan sesuai dengan kebutuhan masyarakat/petani di wilayah. Selanjutnya, berbagai upaya tersebut perlu didukung antara lain oleh 1) pengembangan kelembagaan, 2) Pembinaan penelitian, pengembangan dan penerapan/ pengelolaan alsintan serta inovasi teknologi lainnya yang sesuai dengan potensi wilayah, 3) pembangunan prasarana ekonomi yang dapat menunjang percepatan pengembangan traktor dan sekaligus pembangunan pertanian wilayah dan 4) adanya koordinasi dari seluruh pihak yang terkait dalam pembangunan suatu wilayah.

\section{c. Pendekatan Sumberdaya Manusia}

Inisiatif untuk mengembangkan traktor roda dua diharapkan timbul dari masyarakat/petani yang bisa melihat berbagai peluang untuk melakukan efisiensi usahatani dan meningkatkan nilai tambah. Dalam menumbuhkan inisiatif tersebut, diperlukan pemberdayaan masyarakat agar mereka mampu menjadi pelaku utama dalam pengembangan traktor roda dua tersebut dengan meningkatkan pengetahuan dan ketrampilannya melalui pendidikan dan pelatihan yang efektif dan berkesinambungan. Melalui penerapan traktor dan alsintan lainnya akan terjadi perubahan dimana disatu pihak secara absolut dan relatif tenaga kerja usahatani padi sawah menurun, tetapi dipihak lain citra, kualitas dan produktivitas tenaga kerja khususnya pada usahatani padi di lahan sawah meningkat, sehingga pada akhirnya tenaga kerja muda yang cenderung bekerja di perkotaan akan beralih kerja kembali di perdesaan.

\section{SIMPULAN DAN SARAN}

\section{Simpulan}

Ketersediaan traktor roda-2 relatif berfluktuasi dengan kecenderungan meningkat selama empat tahun terakhir ini. Jumlah traktor roda-2 menurun dari 16.945 unit pada tahun 2004 menjadi 13.520 unit pada tahun 2005, tetapi kemudian meningkat secara konsisten menjadi 15.654 unit pada tahun 2006 dan 16.970 unit pada tahun 2007.

Berdasarkan analisis kelayakan ekonomis usaha jasa traktor roda dua dengan indikator Revenue-Cost Rasio (R/C), Pay Back Period (PBP), dan titik impas, usaha traktor adalah layak untuk dikembangkan dalam rangka mendukung akselerasi pengembangan usahatani padi berorientasi agribisnis dan agroindustri. Nilai ketiga indikator tersebut masing-masing adalah $\mathrm{R} / \mathrm{C} 1,4, \mathrm{PBP} 2,7$ tahun serta titik impas 30,8 ha tahun ${ }^{-1}$.

Beberapa masalah maupun kendala dalam pengembangan traktor roda dua pada padi sawah di Jawa Barat adalah introduksi traktor belum sesuai dengan kondisi ekonomi maupun sosial budaya setempat, badan litbang pertanian dan industri belum menghasilkan teknologi traktor untuk padi yang sesuai dengan kondisi di berbagai agroekosistem lahan sawah. Selain itu, kebijakan pemerintah masih terfokus pada penyediaan bantuan traktor tanpa upaya pembinaan, dan koordinasi antar subdinas pada satu dinas yang sama dan antar instansi/dinas terkait masih belum optimal.

\section{Saran}

Pengembangan traktor roda-2 seharusnya diintegrasikan dengan program Gerakan Multi Aktivitas Agribisnis (Gemar) dalam suatu program terpadu yang dilaksanakan melalui pendekatan sistem, wilayah, dan pemberdayaan masyarakat/petani, serta dalam implementasinya melibatkan seluruh pihak terkait termasuk swasta dan masyarakat/petani setempat.

Pengembangan alsintan padi sawah tidak cukup dilakukan dengan memberikan bantuan alsintan secara langsung kepada petani tetapi harus didukung berbagai program/kegiatan lainnya dalam kerangka pengembangan agribinis/ agroindustri, seperti: 1) perbaikan infrastruktur pedesaan termasuk jalan usahatani; 2) rehabilitasi dan restrukturisasi industri traktor; 3) revitalisasi sistem perkreditan untuk penyediaan traktor roda-2 bagi kelompok tani maupun gapoktan dan untuk usaha jasa alsintan, pengusaha bengkel/perawatan, industri kecil dan menengah, serta penyediaan suku cadang; 4) pembinaan dan pelatihan SDM secara berkala dan berkelanjutan; dan 5) pembentukan jaringan kerja- 
sama dengan mekanisme kerja yang terarah dan terkoordinasi dalam suatu program maupun kegiatan yang terpadu, konsisten, dan berkelanjutan.

\section{DAFTAR PUSTAKA}

Ananto, EE, Sutrisno, Astanto dan Soentoro. 1993. Pengembangan alat dan mesin pertanian menunjang sistem usahatani dan perbaikan pasca panen di lahan pasang surut Sumatra Selatan. Badan Penelitian dan Pengembangan Pertanian, Jakarta.

Ananto, EE, Handaka dan A. Setyono. 2004. Mekanisasi dalam perspektif modernisasi pertanian. Hal. 443-466 dalam Ekonomi Padi dan Beras Indonesia. Kasryno et al. (Eds). Badan Penelitian dan Pengembangan Pertanian, Jakarta.

Badan Litbang Pertanian. 2005. Prospek dan arah pengembangan agribisnis: Dukungan Aspek Mekanisasi Pertanian. Badan Penelitian dan Pengembangan Pertanian, Jakarta.

Chamber, R. 1992. Participatory Rural Appraisals: Past, Present, and Future. Newsletter No. 15/16, February 1992. FAO, Rome and the International Rural Development Centre (IRDC), Upsalla.

Deptan. 2006. Kebijakan dan program penanganan pasca panen. Direktorat Penanganan Pasca Panen, Direktorat Jenderal Pengolahan dan Pemasaran Hasil Pertanian, Departemen Pertanian, Jakarta.

Diperta Prop. Jawa Barat. 2003. Laporan Tahun 2003. Dinas Pertanian Tanaman Pangan dan Hortikultura Propinsi Jawa Barat, Bandung.

Diperta Prop. Jawa Barat. 2004. Laporan Tahun 2004. Dinas Perta-nian Tanaman Pangan dan Hortikultura Propinsi Jawa Barat, Bandung.
Diperta Prop. Jawa Barat. 2005. Laporan Tahun 2005. Dinas Perta-nian Tanaman Pangan dan Hortikultura Propinsi Jawa Barat, Bandung.

Diperta Prop. Jawa Barat. 2006. Laporan Tahun 2006. Dinas Perta-nian Tanaman Pangan dan Hortikultura Propinsi Jawa Barat, Bandung.

Diperta Prop. Jawa Barat. 2007. Laporan Tahun 2007. Dinas Perta-nian Tanaman Pangan dan Hortikultura Propinsi Jawa Barat, Bandung.

Friyatno, S, HP Rachman dan Supriyati. 2004. Kelembagaan jasa alat dan mesin pertanian (Alsintan) Hal. 261-285 dalam Prosiding Efisiensi dan Daya Saing Usahatani Beberapa Komoditas Pertanian di Lahan Sawah. Saliem et al. (Eds.). Pusat Penelitian dan Pengembangan Sosial Ekonomi Pertanian, Bogor.

Mathias, E. 1994. Indigenous knowledge and sustainable development. IIRR Working Paper No. 53. International Institute of Rural Reconstruction, Silang, Cavite, Philippines.

Simatupang, P, A Purwoto, EE Ananto dan J. Situmorang. 1995. Pola pengembangan mekanisasi pertanian di Indonesia. Pusat Penelitian Sosial Ekonomi Pertanian, Bogor.

Soentoro, 1998. Pengembangan mekanisasi pertanian: Tinjauan Aspek Ekonomi dan Kelembagaan. Hal 26-36 dalam Prosiding Perspektif Pemanfaatan Mekanisasi Pertanian Dalam Peningkatan Daya Saing Komoditas. Erwidodo et al. (Eds.). Pusat Penelitian Sosial Ekonomi Pertanian, Bogor. 